\title{
Scientific Project as a Tool to Stimulate Teenagers in the Field of Science
}

\author{
${ }^{1}$ Ana Cristina da Palma Camargo, ${ }^{1}$ Marina Schwarz \\ ${ }^{1}$ Regina Mara da Fonseca, ${ }^{2}$ Diógenes Batista da Silva \\ ${ }^{1}$ Colégio Bandeirantes, ${ }^{2}$ São Paulo University, USP, Brazil
}

\begin{abstract}
This paper was written to share a Brazilian case study related to Science Education. It has been used with teenagers at the ages of fifteen and sixteen in a private school. Since 1998, pupils have been invited to attend a one year extracurricular project in the field of Biotechnology. Biotechnology Project is an educational project used as a tool to stimulate the pursuit of a scientific career and experience the routine of a researcher. Attending this project, teenagers have the opportunity to (1) engage in some contemporary issues in biotechnology including bioethics, (2) manipulate lab materials, (3) develop a number of important skills in order to enhance their capability in teamwork and communication, and (4) get information related to Social Entrepreneurship.

Although Science Education is complex, it is essential to have an educational program in school that can measure and/or track the develop programs to foster motivation to follow scientific careers. Science is usually part of the school program. However in Bandeirantes we focus on high quality education bringing the school into line with workplaces where entrepreneurship is practiced with pupils. Science teachers are concerned about the students understanding of real Science. Understanding how students make decisions about their professional choices is key for teachers to find ways to support them more effectively.
\end{abstract}

\section{Introduction}

Innovation in science and technology education has been recognised as an essential component for a country's development. It needs to have a research base, to be guided by policy makers towards relevant intentions and implemented at the practitioner level in meaningful and rewarding ways.

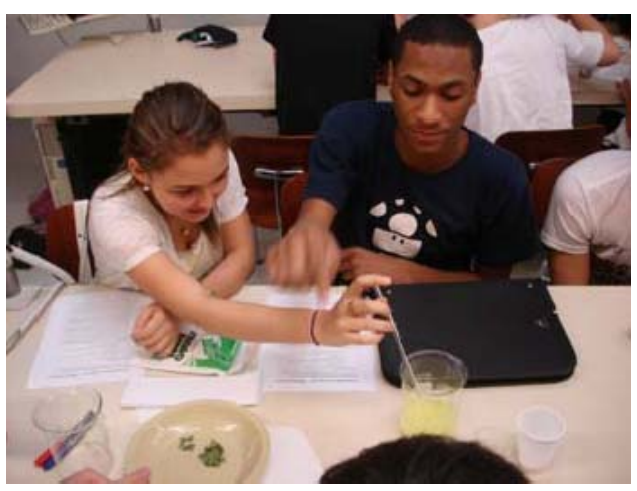

Focus on Ethics and Biotechnology Education in contemporary Biology programs is an important issue to be considered in Science Education [1], [2], [5]. Any Science Education (SE) program should highlight the relevance of the subject reported in the news media, showing how important Biology and Ethics are to the population in general [5]. In addition, SE should motivate students and arouse interest towards science learning [8]. Despite worldwide attempts to SE, science educators are still concerned about the decline of student's interest and lack of relevance in SE in school science. It is thus appropriate to establish pertinent and interesting ways to motivate science learning at school [8]. In order to develop an applicable policy of SE at school, some important goals have to be considered as a possible answer to the question "What should all students know and be able to do?”

1. share information;

2. deal with technology;

3. be well informed/updated;

4. have team spirit;

5. have critical thinking;

6 . be self-organized [7]. Other fairly recent 
document that emphasizes goals of Education is the Melbourne Declaration on Educational Goals for Young Australians which sees, in special, successful learners as students who are motivated to reach what they are truly capable of [4].

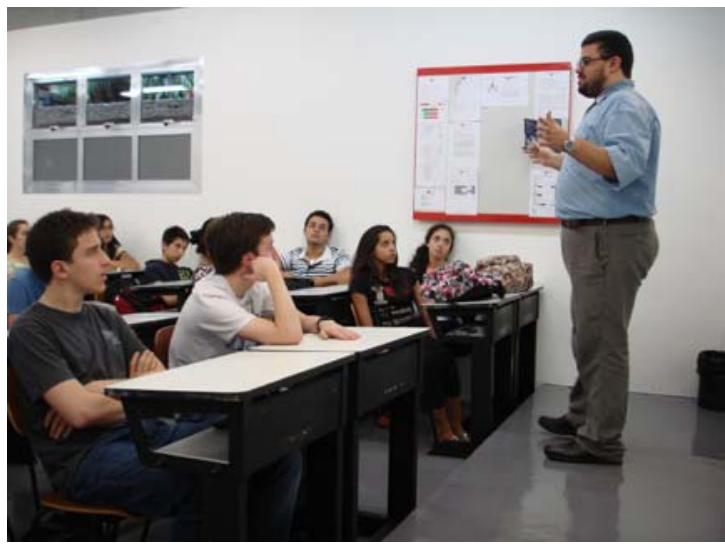

A number of individuals and programs have demonstrated the potential for catalyzing widespread improvements in science education by building and nurturing appropriate partners [6]. One important tool to develop scientific programs and partnerships at school are educational projects [3]. Colégio Bandeirantes is a private school which has been amassing impressive resources to wire and equip teachers and students with powerful interactive technologies and educational projects to motivate teaching and learning processes. The school has been working with a one-year educational project called Biotechnology Project since 1998.

Attending this project, teenagers have the opportunity to (1) engage in some contemporary issues in biotechnology including bioethics, while at the same time they can (2) manipulate lab materials, (3) develop a number of important skills in order to enhance their capability in teamwork and communication, and (4) get information related to Social Entrepreneurship, one important field of knowledge nowadays in any kind of activity, including a scientific career.

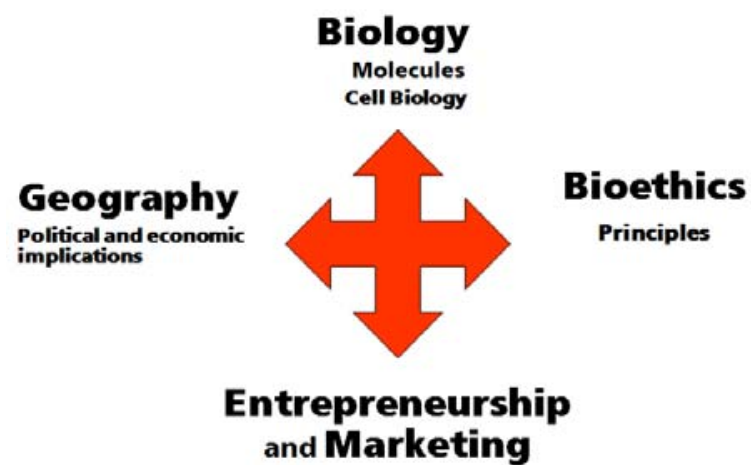

\section{Methodology}

Three overarching questions guided us to create our methodology:

1. Are teenagers naturally interested to engage in the world of Science?

2. Is it possible to stimulate teenagers to pursue a scientif career using a project as a tool ?

3. Is Biotechnology Project useful for teachers and pupils to promote a scientific education?

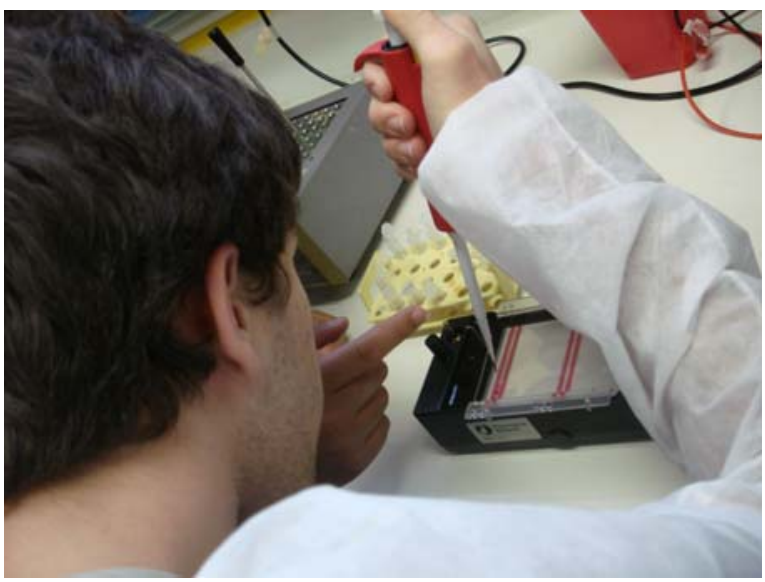

In our one year project, with once a week meeting (two and a half hours), 36 students:

(1) take part in lectures related to different fields of knowledge (Biotechnology, Geography, Chemistry, Bioethics, Social Entrepreneurship and Marketing);

(2) attend classes about basic knowledge in Cytology, Genetics, Chemistry and Molecular Biology (Appendix 2);

(3) visit University laboratories (University of São Paulo) and Research centers;

(4) take part in practical activities organized by experts.

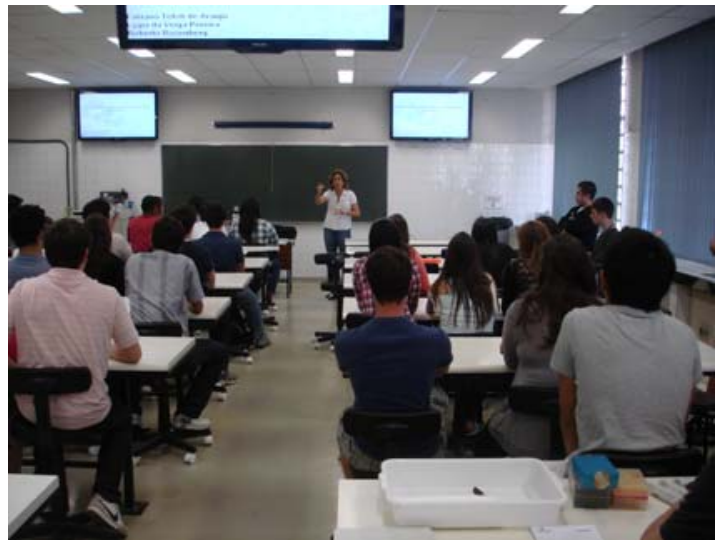

During these activities, they frequently work in groups, researching and debating about different issues 
including bioethics, stem cells, clones, GM food and gene therapy. In a virtual learning webpage on Colégio Bandeirantes website, students can get information and publish their works. At the end of the project, they have to develop a proposal including marketing, social entrepreneurship, transgenic products and scientific knowledge. There is an individual evaluation about specific knowledge in Biotechnology to select five best students to go to University laboratories to experience the routine and take part in scientific activities for two weeks.

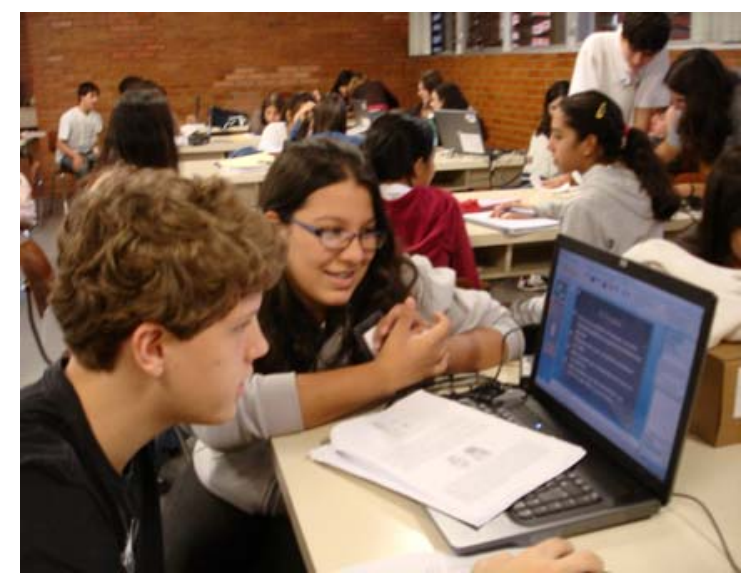

\section{Results}

Data were collected using a series of online written questions requiring individual written responses (Appendix 1). From a total of 36 students who took part in Biotechnology Project in 2011, 36 online questionnaires were analyzed (Table 1 and Table 2).

As would be hoped, most pupils developed critical understanding of real Science and the routine of a researcher after taking part in the project. Having experienced this way of learning, pupils were more aware of the way scientific knowledge develops along the time. According to Table 1, Biotechnology project was considered important or very important for at least $80 \%$ of our students in each objective evaluated.
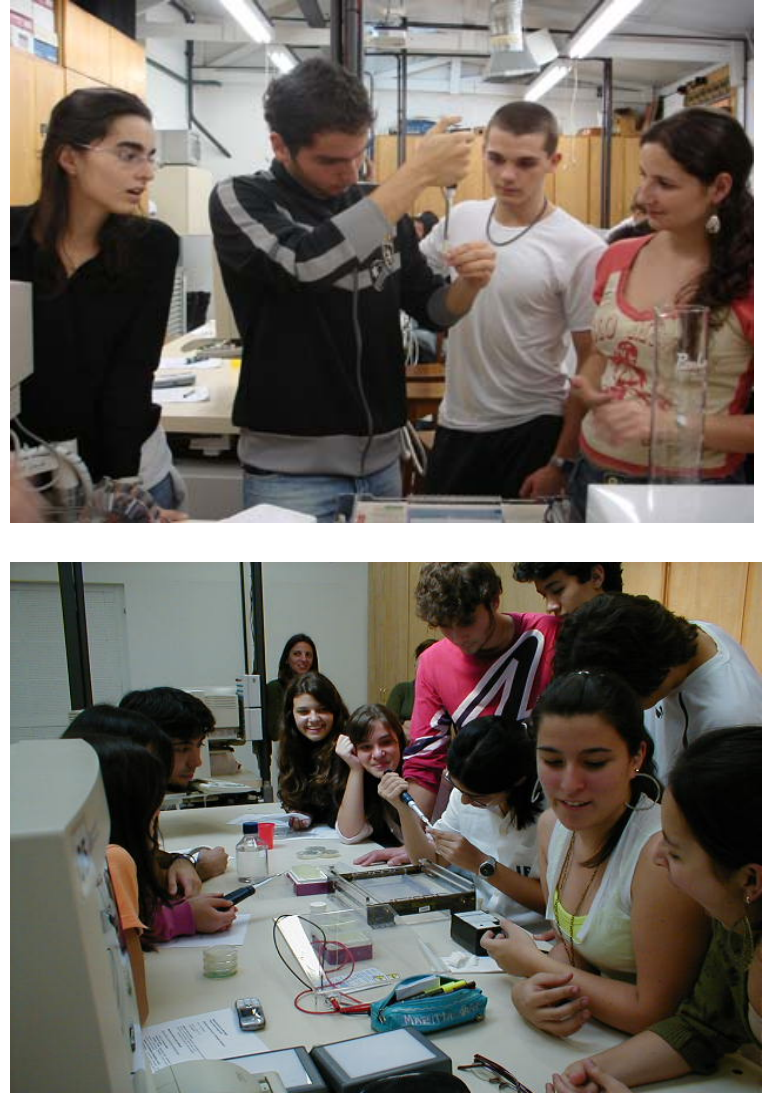

Students reported that their interest in developing a scientific research after taking part in the project has grown (Table 2). Before Biotechnology project $46 \%$ of the students had no interest in this kind of research, whereas after the project this number decreased to 22\%. Observing Table 2, data suggests significant motivation in developing a scientific research inside the group of students. On the other hand, a significant a number of students who had little interest in this activity before taking part in the project changed their minds and started thinking about this possibility seriously.

In 2012, 32 students were asked if they intended to develop scientific research during the period of the university or during their professional career. Most students $(84.4 \%)$ responded that aim to develop scientific research (Figure 1). The same pupils were asked about the factors that stimulate the desire to develop a scientific research and what influences them negatively. We performed a qualitative analysis of students' answers and these were grouped into different categories.

Table 3 presents the factors that discourage students to conduct a scientific research. The factor that was cited by most students (present in 9 responses) is the low financial investment in research.

Most responses (18 students), believe that the opportunity to discover something important for 
society is a factor that stimulates the desire to conduct a scientific research. The findings directly related to medical or health were the most mentioned (9 questionnaires), while only 1 student related the research to the possibility of developing new technologies and 5 students said they would want to collaborate with the scientific community.

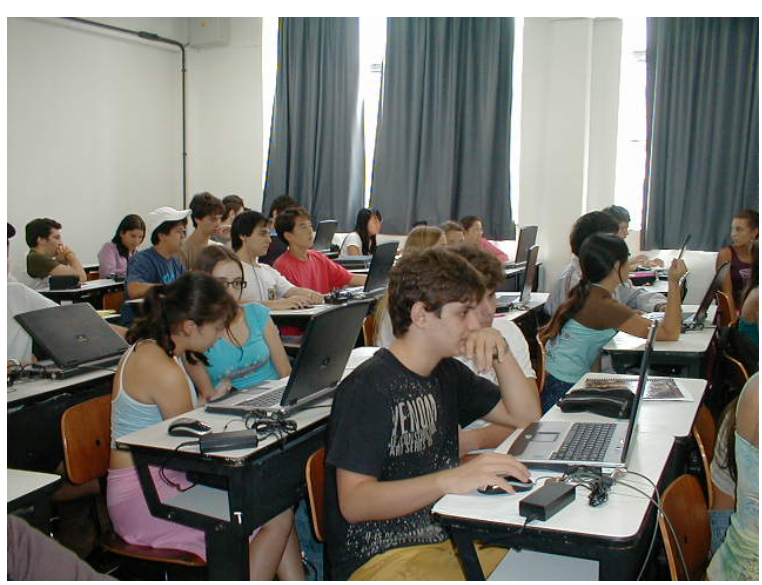

Table 1. Results - 2011 - 36 questionnaires analyzed

\begin{tabular}{|c|c|c|c|c|c|}
\hline $\begin{array}{l}\text { Biotechnology Project was } \\
\text { important to: }\end{array}$ & $\begin{array}{l}\text { I don't } \\
\text { know. }\end{array}$ & $\begin{array}{l}\text { It was not } \\
\text { important. }\end{array}$ & $\begin{array}{c}\text { It was } \\
\text { important. }\end{array}$ & $\begin{array}{l}\text { It was very } \\
\text { important. }\end{array}$ & Other \\
\hline $\begin{array}{l}\text { Promote the improvement in your } \\
\text { critical thinking about themes } \\
\text { related to Biotechnology }\end{array}$ & $0 \%$ & $11 \%$ & $30 \%$ & $54 \%$ & $0 \%$ \\
\hline $\begin{array}{l}\text { Encourage independent research } \\
\text { and research groups. }\end{array}$ & $0 \%$ & $8 \%$ & $73 \%$ & $7 \%$ & $0 \%$ \\
\hline $\begin{array}{l}\text { Stimulate to work in groups and } \\
\text { deal with different ideas. }\end{array}$ & $5 \%$ & $5 \%$ & $65 \%$ & $24 \%$ & $0 \%$ \\
\hline $\begin{array}{l}\text { Promote direct contact with experts } \\
\text { from different fields. }\end{array}$ & $0 \%$ & $5 \%$ & $19 \%$ & $65 \%$ & $11 \%$ \\
\hline $\begin{array}{l}\text { Make it easier to learn specific } \\
\text { topics through getting in touch with } \\
\text { experts. }\end{array}$ & $0 \%$ & $8.3 \%$ & $54.1 \%$ & $37.6 \%$ & $0 \%$ \\
\hline $\begin{array}{l}\text { Make you experience the routine of } \\
\text { a researcher through lab activities. }\end{array}$ & $0 \%$ & $3 \%$ & $41 \%$ & $57 \%$ & $0 \%$ \\
\hline
\end{tabular}

Table 2. Results - 2011 - 36 questionnaires analyzed

\begin{tabular}{|c|c|c|}
\hline $\begin{array}{c}\text { Your interest in } \\
\text { developing a scientific } \\
\text { research: }\end{array}$ & Before taking part in the project & After taking part in the project \\
\hline I don't know. & $0 \%$ & $0 \%$ \\
\hline $\begin{array}{c}\text { Was zero. I didn't want to } \\
\text { do this activity. }\end{array}$ & $3 \%$ & $3 \%$ \\
\hline $\begin{array}{c}\text { Was minimum. I had little } \\
\text { interest in this activity. }\end{array}$ & $43 \%$ & $19 \%$ \\
\hline $\begin{array}{c}\text { Was reasonable. I had } \\
\text { thought of doing that. }\end{array}$ & $38 \%$ & $46 \%$ \\
\hline $\begin{array}{c}\text { Was significant. I've } \\
\text { already wanted to do this. }\end{array}$ & $8 \%$ & $24 \%$ \\
\hline $\begin{array}{c}\text { It has always been great. I } \\
\text { want to be a researcher. }\end{array}$ & $8 \%$ & $8 \%$ \\
\hline
\end{tabular}

Table 3. Result - 2012 - Factors that discourage 32 students to conduct a scientific research, grouped into ten different categories 


\begin{tabular}{|l|l|}
\hline Professional recognition below the desired & $12,5 \%$ \\
\hline Lack of financial incentives / low salary & $28,1 \%$ \\
\hline High competition in the field of research & $6,2 \%$ \\
\hline Hard working & $25 \%$ \\
\hline Consuming time & $12,5 \%$ \\
\hline Possibility of frustration with the results & $15,6 \%$ \\
\hline Possibility of using the results unethically & $6,25 \%$ \\
\hline Too much time indoors & $6,25 \%$ \\
\hline Controversial issues related to scientific research & $6,25 \%$ \\
\hline Frequent trips & $3,1 \%$ \\
\hline
\end{tabular}

Figure 1. Result - 2012 - Do the students intend to develop scientific research during the period of the university or during their professional career? (32 students responded)

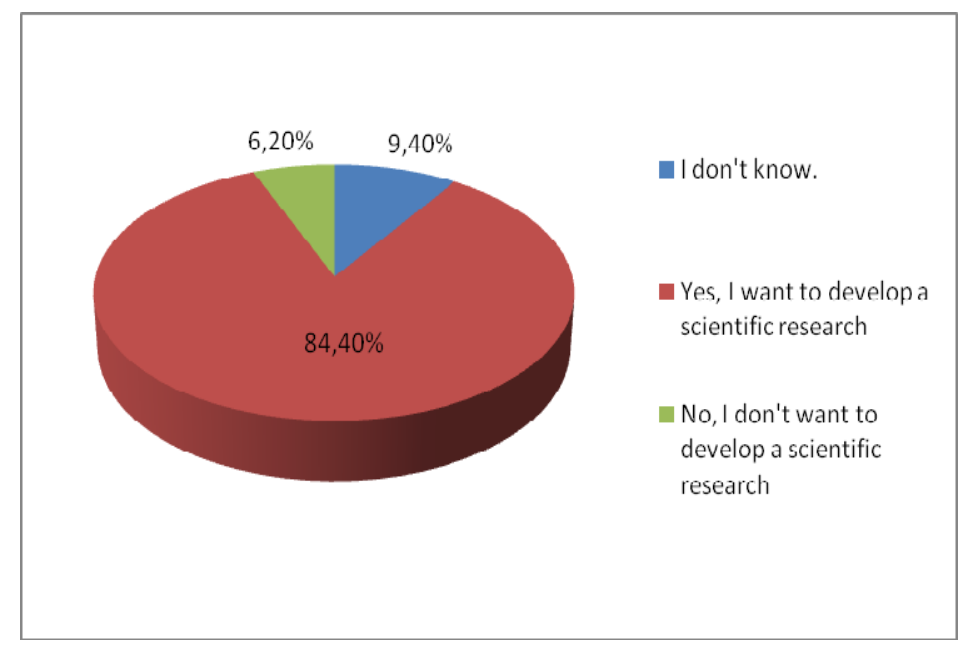

\section{Conclusion}

Data suggest that Biotechnology Project can be considered an important tool to promote scientific education and to stimulate the pursuit of a scientific carrier. Students reported they felt significant improvement in their critical thinking about themes related to Biotechnology and they could see Science field as a way to promote Social Entrepreneurship. The contact with experts was a point evaluated by students as an important way to acquire specific knowledge and experience the reality of Science in Brazil. It is fundamental to take care in any possible generalization of findings [9]. These findings were derived from one context or under one set of specific conditions: this case study was carried out with teenagers of a certain social and economic background, with certain ability levels and previous interest in Science. However, it can be useful if customized to the needs of each school program.

Despite the complexity of the subject Science Education, the potential advantages to work out any educational program to measure and/or track the development of students interest in schools before going to their future professional fields are easy to figure out. They include:

1. Indicating that the way Science has been worked out inside regular classes is seen as an important aspect to be checked out in curriculum in schools;

2. Inspiring the development of curricula and teaching activities that foster students interest about Science; 
3. Providing a way of articulating and evidencing the value of high quality science education;

4. Bringing schools into line with workplaces where entrepreneurship is practiced with pupils;

5. Helping Science teachers to be more precise in their understanding of real Science;

6. Understanding more about different manners been used by pupils to make decisions about their professional choices and how teachers and others can support them more effectively;

7. Providing formative feedback to pupils to enable them to develop their critical thinking related to Science more effectively .

\section{References}

[1] Caballero, A.M., "Algunas ideas del alumnado de secundaria sobre conceptos básicos de genética”, Enseñanza de las Ciencias, 2008, 26 (2), pp.227-237.

[2] Dawson, V. and Taylor, P., "Do adolescents bioethical decision differ from those of experts?”, Journal of Biological Education, 2000, 34(4), pp.184-188.

[3] Hernández, F. E and Ventura, M., A Organização do Currículo por Projetos de Trabalho- O conhecimento é um caleidoscópio. Brasil: Artmed - 5o Edição, 1998.

[4] Holbrook, J. "Education through science as a motivacional innovation for science education for all". Science Education International. Vol. 21, No. 2, June 2010, 80-91.

[5] Pérez, P., Martinez J.M., Pilaer M. Y. and Martínez, M. "La Sección de Cartas al Editor: un planteamiento científico y social en la didáctica de las ciências”. Enseñanza de las Ciencias, 2007, 25(2), pp. 195-198.

[6] Rhoton, J. and Shane, P. "Teaching science in the twentyfirst century”. NSTA press, Arlington, Virginia, 2006, pp. 316.

[7] Stefanadis, C. I. "Characteristics of the Good Researcher: Innate Talent or Acquired Skills?” Hellenic, J. Cardiol 47: 52-53, 2006.

In http://www.hellenicjcardiol.com/archive/full_text/2006/1/200 6_1_52.pdfUH. (Acessed date: 10 January, 2009)

[8] Rannikmäe, M. "Popularity and relevance of Science Education literacy: using a Context-based Approach". Science Education Internacional. Vol.21, No. 2, June 2010, 116-125.
[9] Jaeger, R. "Complementary Methods for Research in Education [Paperback]" - Richard M. Jaeger (Editor), American Educational Research Association (Corporate Author), 2nd Edition, 2008.

\section{Acknowledgements}

Special thanks should be given to Mauro de Salles Aguiar - President Director for his valuable support to develop this project. We wish to thank PhD. Lygia Pereira and her group of researchers (São Paulo University) for their valuable technical support on this project and Marilena Amorim Piva - English Teacher for her professional guidance and support giving useful and constructive recommendations on this paper.

\section{Appendix 1}

Biology Department

Biotechnology Project

Yearly Project Evaluation

A. When you entered the Biotechnology Project, how would you evaluate, from $\mathbf{0}$ to $\mathbf{1 0}$ :

1. Your level of specific biotechnology knowledge? ( )

2. Your ability to critically analyze themes related to Biotechnology? ( )

3. Your comprehension level about the daily lives of researchers? ( )

4. Your intention to become a researcher? ( )

B. After your participation in the Biotechnology Project, re-evaluate the same items, also using grades from 0 to 10 :

1. Your level of specific biotechnology knowledge? ( )

2. Your ability to critically analyze themes related to Biotechnology? ( )

3. Your comprehension level about the daily lives of researchers? ( )

4. Your intention to become a researcher? ( )

C. Use the criteria numbered below to evaluate the importance of the Biotechnology Project in each item in the table;

1. I don't know.

2. It was not important.

3. It was important.

4. It was very important. 


\begin{tabular}{|ll|l|}
\hline 1. & $\begin{array}{l}\text { To provide an informed and } \\
\text { improved critical view of } \\
\text { Biotechnology related } \\
\text { themes. }\end{array}$ & \\
\hline 2. & $\begin{array}{l}\text { To provide the acquisition of } \\
\text { new knowledge related to } \\
\text { Biotechnology. }\end{array}$ & \\
\hline 3. & $\begin{array}{l}\text { To stimulate autonomous and } \\
\text { group research. }\end{array}$ & \\
\hline 4. & $\begin{array}{l}\text { To stimulate group work and } \\
\text { Idea debates. }\end{array}$ & \\
\hline 5. & $\begin{array}{l}\text { To provide direct contact } \\
\text { with specialists in different } \\
\text { areas of knowledge. }\end{array}$ & \\
\hline 6. & $\begin{array}{l}\text { To stimulate the production } \\
\text { of texts in response to } \\
\text { exercises related to } \\
\text { biotechnology or texts to } \\
\text { share the acquired } \\
\text { knowledge. }\end{array}$ & \\
\hline 7. & $\begin{array}{l}\text { To stimulate the pursuit of a } \\
\text { scientific career. }\end{array}$ & \\
\hline 8. & $\begin{array}{l}\text { To facilitate the learning of } \\
\text { specific knowledge through } \\
\text { contact with researchers. }\end{array}$ & \\
\hline 9. & $\begin{array}{l}\text { To experience the routine of } \\
\text { a researcher by doing } \\
\text { practical activities and } \\
\text { visiting research laboratories. }\end{array}$ & \\
\hline
\end{tabular}

D. Any other observation about the project (comments and suggestions)

\section{Apendix 2: Basic knowledge required}

\section{$\underline{\text { Topics in Molecular Biology }}$}

Basic structure of cells

DNA-RNA

Gene - Structure and function

Genetic code

Protein synthesis

Restriction enzymes

Molecular cloning

Transgenic techniques

\section{$\underline{\text { Topics in Chemistry }}$}

Organic molecules (structure, functions)

Electrophoresis 